B. Assumed rights; or
B. method, or process contained in thls report

use of any inform any liabilities with

As used in thation, apparatus, respect to the use of or for may not infringe

ployee or cod in the above, "Per, method, or procese of, or for damages resulf

such empontractor of the corson acting on becess disclosed in this report

disseminase or contractor of ission, or emplo of the Commission"

with the

th the Commission, or hiccess to, any inform, or employee of anctor, to the extent em-

or his employment with such contrsuant to his employment prepares,

General, Miscellaneous, and Progress Reports (TID-4500, 45th Ed.)

\title{
PRODUCTION OF TRANSPLUTONIUM ELEMENTS AT SAVANNAH RIVER
}

\author{
by \\ W. P. Overbeck \\ C. H. Ice G. Dessauer
}

A Paper Prepared for Presentation at the Winter Meeting of the American Nuclear Society, November 15-18, 1965, Washington, D. C.

REIEASED FOR ANWOUNCAMENT

IN NUCLERR SOIENCE ABSTRACTS

\author{
E. I. DU PONT DE NEMOURS \& COMPANY \\ SAVANNAH RIVER LABORATORY \\ AIKEN, SOUTH CAROLINA \\ CONTRACT AT(OT-2).1 WITH THE \\ UNITED STATES ATOMIC ENERGY COMMISSION
}




\section{DISCLAIMER}

This report was prepared as an account of work sponsored by an agency of the United States Government. Neither the United States Government nor any agency Thereof, nor any of their employees, makes any warranty, express or implied, or assumes any legal liability or responsibility for the accuracy, completeness, or usefulness of any information, apparatus, product, or process disclosed, or represents that its use would not infringe privately owned rights. Reference herein to any specific commercial product, process, or service by trade name, trademark, manufacturer, or otherwise does not necessarily constitute or imply its endorsement, recommendation, or favoring by the United States Government or any agency thereof. The views and opinions of authors expressed herein do not necessarily state or reflect those of the United States Government or any agency thereof. 


\section{DISCLAIMER}

Portions of this document may be illegible in electronic image products. Images are produced from the best available original document. 


\begin{abstract}
The Savannah River Plant has been engaged in two programs for production of transplutonium elements. The first, a research effort, involved the irradiation of plutonium to produce target material for the Oak Ridge HFIR. The second is a production effort to produce $3 \mathrm{~kg}$ of ${ }^{244} \mathrm{~cm}$. These programs have recently been combined in a manner that enhances both, through the use of a new mode of high-flux operation for the Savannah River reactors. Extended irradiation of the HFIR target material has been accomplished in a high-flux test at $5.4 \times 10^{15}$ neutrons/ $\left(\mathrm{cm}^{2}\right)(\mathrm{sec})$, and the high-flux mode will be used to accelerate the production of $244 \mathrm{~cm}$.
\end{abstract}




\section{CONTENTS}

$\underline{\text { Page }}$

Introduction . . . . . . . . . . 5

The Transplutontum Campaigns . . . . . 6

Curium I............... 8

The Hlgh-Flux Test . . . . . . . 10

Curium II . . . . . . . . . . 12

Conclusions . . . . . . . . . . 15

References . . . . . . . . . 16 


\section{LIST OF TABLES AND FIGURES}

Table

$\underline{\text { Page }}$

I Results of Transplutonium Campaigns . . . . 8

II Main Products of Curium II . . . . . . 15

\section{Figure}

1 Chronology of Savannah River Transplutonium

Programs . . . . . . . . . . . . 5

$2 \quad$ Rack ................ . 7

3 Yield of Isotopes from Irradiation of ${ }^{239} \mathrm{Pu}$. 9

4 Products of Savannah River High-Flux

Irradiation ............. 12

5 Isotopes Irradiated in High-FIux Test... . 13

6 Large-Scale Production of Curium . . . . . I4 


\section{PRODUCTION OF TRANSPLUTONIUM ELEMENTS AT SAVANNAH RIVER}

INTRODUCTION

Savannah River first became involved in the transplutonium program in 1959, with the irradiation of $239 \mathrm{Pu}$ to produce about 1 kilogram of $242 \mathrm{Pu}$ plus $1 \mathrm{kllogram}$ of mixed ${ }^{243} \mathrm{Am}$ and $244 \mathrm{Cm}$. Th1s was part of a program that was summarized in 1963 by D. E. Ferguson and other members of the staff of the Oak Ridge National Laboratory. (1) The materials produced were to be used as targets in the High FIux Isotope Reactor (HFIR) at Oak Ridge.

At Savannah River, this work was done in two transplutonium campaigns, which are listed first in the chronology shown in Figure 1. These two campaigns have been completed and the products have been separated and purified.

A major change in the program developed late in 1963, when Savannah River was also asked to produce $3 \mathrm{kilograms}$ of ${ }^{244} \mathrm{~cm}$ for experimental use as a radioisotopic heat source for the space program. Although the production of ${ }^{244} \mathrm{Cm}$ is a distinctly separate activity

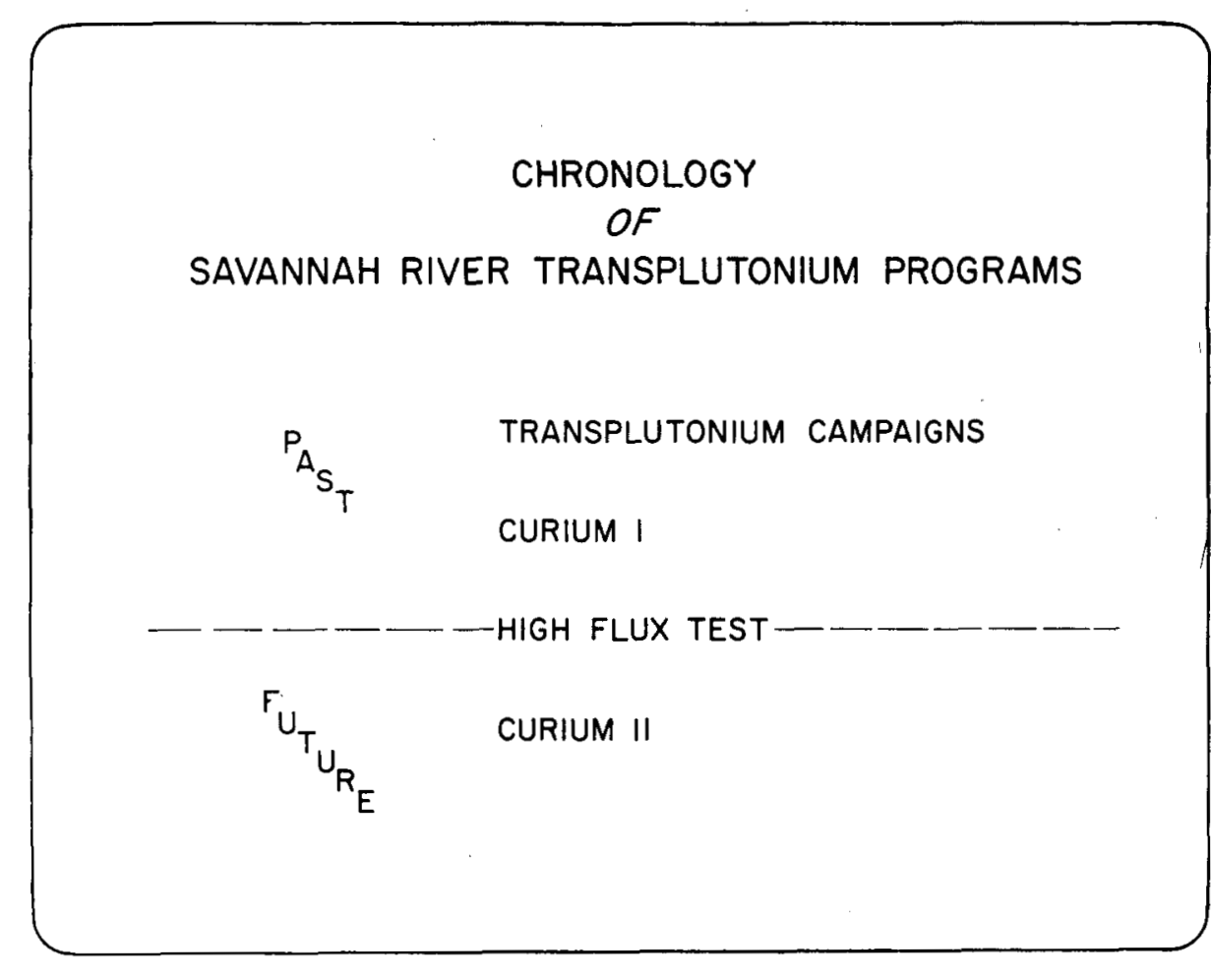

FIGURE 1 
from the original transplutonium program, it starts out in the same way; that 1s, with a long-term 1rradiation of ${ }^{239} \mathrm{Pu}$. However, significantly larger quantities are involved. Part of this ${ }^{244} \mathrm{Cm}$ production program has been completed, and 1t is represented by the item curium I, which appears next in the chronology.

In planning the $244 \mathrm{~cm}$ production program, we recognized that better results might be obtained by performing the irradiation in two steps: the first at a neutron flux of the order of $10^{14}$ and the second at a flux of about $10^{15}$. To explore this possibility, an experimental test of high-flux operation was successfully conducted. A flux of $5.4 \times 10^{15}$ neutrons/( $\left.\mathrm{cm}^{2}\right)(\mathrm{sec})$ was achleved, exceeding the record set by the Russian SM-2 reactor by more than a factor of two. Th1s operation has continued while the products of Curium I are being separated and prepared for continued irradiation.

In reviewing our plans for the high-flux test, the AEC's Transplutonium Program Committee recognized that the time scale of the original transplutonium program could be compressed by returning the HFIR target material to this high-flux environment; this was done.

Although the second part of the curlum production program, Curlum II, remains to be done, the prospects are already very favorable for the research programs on the transplutonium elements. The total amount of transplutonium elements in existence is about ten times as great as was first expected, and we are 12 to 18 months ahead of the schedules outlined in 1963. One should not conclude from this that the research programs are chance beneficiaries of a production program. The production program could not have proceeded so expeditiously if so much of the technology had not already been developed in the research programs.

Several technical papers on various aspects of the Savannah River work have been published and others are in the process of publication. I shall summarize this work and show its relation to the over-all program for the production of transplutonium elements.

\section{THE TRANSPLUTONIUM CAMPAIGNS}

For the original transplutonium campaigns, coextruded rods of plutonium-aluminum alloy, clad with aluminum, were prepared by O. J. Wick's Metallurgy Development Division at Hanford. These rods were irradiated at Savannah River for a very Iong time to convert ${ }^{239} \mathrm{Pu}$ to ${ }^{242} \mathrm{Pu},{ }^{243} \mathrm{Am}$, and ${ }^{244} \mathrm{Cm}$. This was done by "incidental" irradiation in reactor loads primarily designed for other purposes. The permissible neutron fiux in the targets was limited by the transfer of heat produced by fissions in the ${ }^{239} \mathrm{Pu}$. As the ${ }^{239} \mathrm{Pu}$ burned up, the targets 
were progressively moved to regions of increasing flux. Except for the brief interruptions required to permit this movement, the irradiation was carried continuously through to completion for each of the two campaigns.

The separations processes used in these campalgns are described in a paper by Eargle, Swindell, and Martens of the Savannah River Plant. (2) The principal problem was that of dissolving and handing the small and very precious amount of target material in equipment that is normaliy used to process large quantities of enrlched uranium. Small residues of this major product might seriously contaminate the specially irradiated plutonium. This was avolded by extensive flushing with nitric acid.

To achieve rapid dissolution of the plutonium-aluminum alloy, a two-step dissolving procedure was used. The aluminum was selectively dissolved in a bolling solution of sodium hydroxide and sodlum nitrate, leaving undissolved actinides. The solution was then acldifled with nitric acid and boiled with potassium fluoride to dissolve the plutonium, americium, and curium.

In extracting the products, advantage was taken of another production program at Savannah River. Mottel and Proctor( 3 ) have described the rack of equipment shown in Figure 2. The idea was originated by

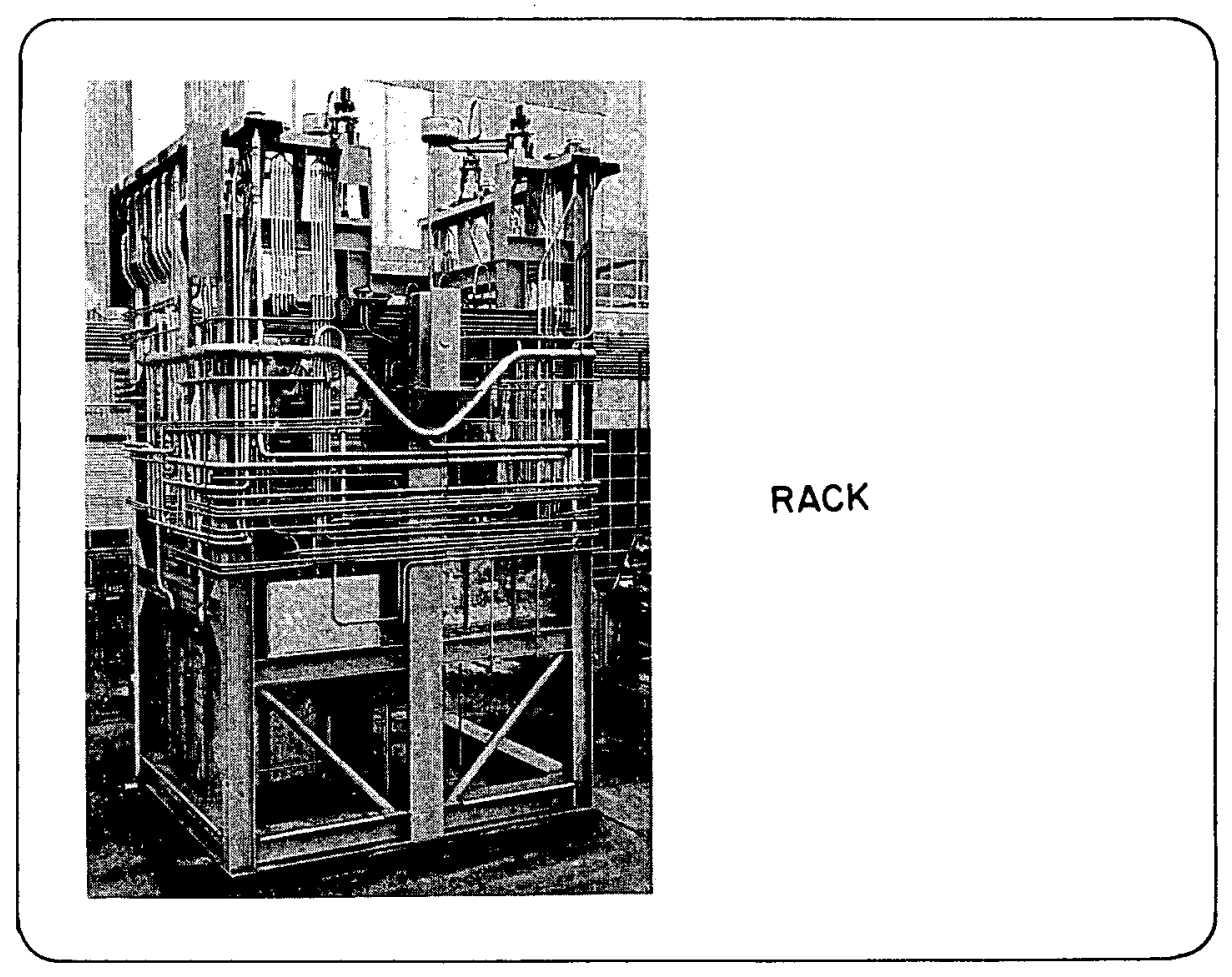

FIGURE 2 
Warren Winsche and was first installed at Savannah River for the recovery and separation of ${ }^{237} \mathrm{~Np}$ and ${ }^{238} \mathrm{Pu}$. This rack contains a prefabricated separations system that can be plugged into existing modules of a Savannah River separations building. The figure shows that the assembly is complicated and compact. Once installed, the rack can be operated remotely. If trouble develops, the entire rack, or certain of its more critical components, can be removed and replaced. These systems are quite reliable and remarkably versatile. The racks include resin beds to separate the plutonium by anion exchange. The plutonium is decontaminated sufficiently to be concentrated, precipitated, and calcined to oxide in unshielded facilities.

Americium and curium isotopes were recovered from the ion exchange raffinate: in the first campaign, by a double sulfate precipitation, and in the second, by batch solvent extraction. These products were shipped as a nitric acid solution to ORNL for final purification.

Recovery of ${ }^{242} \mathrm{Pu}$ averaged $91 \%$ for the two campaigns. $60 \%$ of the americium and curium was recovered in the first campaign and $90 \%$ in the second. Table I summarizes the results of these campaigns and represents the status of the transplutonium program prior to the changes brought about by the curlum production program.

\section{TABLE I}

Results of Transplutonium Campaigns

\begin{tabular}{lccc} 
& $\begin{array}{l}\text { Reactor } \\
\text { Yield, g }\end{array}$ & $\begin{array}{c}\text { Separations } \\
\text { Yield, g }\end{array}$ & $\begin{array}{c}\text { \% } \\
\text { Recovery }\end{array}$ \\
\cline { 2 - 3 } $242 \mathrm{Pu}$ & 1020 & 930 & \\
$243 \mathrm{Am}$ & 380 & 300 & 91 \\
$244 \mathrm{Cm}$ & 410 & 330 & 80
\end{tabular}

CURIUM I

$244 \mathrm{Cm}$ may be the first transplutonium isotope to have substantial practical application. For example, it may be used as a heat source for the space program. Its half-I1fe of 18 years is adequate for most missions, and its specific power ( 2.65 watts/gram) is high enough for thermionic power conversion. The Savannah River program for producing 3 kilograms was designed to meet an early delivery date. Consequently, much intermediate material is left in the pipeline. 
This program started, like the earlier transplutonium campaigns, with the irradiation of ${ }^{239} \mathrm{Pu}$, but the irradiation was a "main line" effort rather than an incidental one. With techniques adapted from other production programs, the plutonium was alloyed with aluminum and fabricated into aluminum-clad billets, which were then extruded into thin-walled fuel tubes. This coextrusion was done on a conventional press without elaborate containment.

A full reactor load was fueled by a uniform mixture of the plutonium-aluminum assemblies and enriched uranium-a.luminum assemblies. Each assembly contained a poison rod of aluminum-lithlum alloy. As the plutonium burned up, the decrease in reactivity was compensated by replacing the burned-up urantum fuel with fresh uranium assemblies and by replacing the poison rods with rods containing less lithium. New mechanical techniques were devised to replace the poison rods, and these techniques were entirely successful.

The strategy of the program is evident in the graphs of Figure 3 , adapted from a paper by Groh, Huntoon, Schlea, Smith, and Springer. (4) The graph on the left shows the reduction in total plutonium content and the growth of ${ }^{243} \mathrm{Am}$ and ${ }^{244} \mathrm{~cm}$. Note that the scale factor for the plutonium differs from that for americium and curium. The graph on the right shows the varying 1sotopic composition of the plutonium. The abscissae for both graphs are in exposure units of $10^{21}$ neutrons $/ \mathrm{cm}^{2}$.

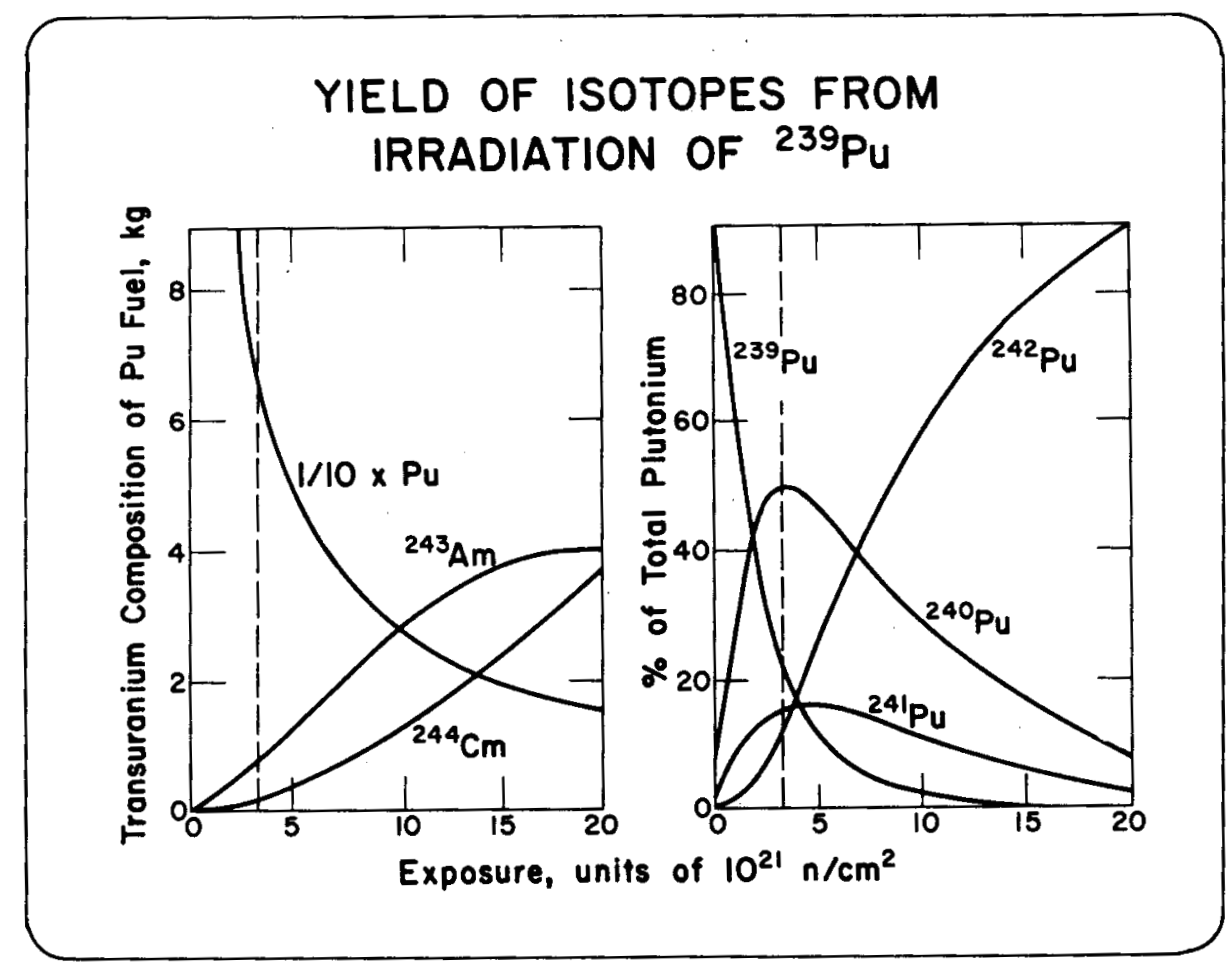

FIGURE 3 
Early in the planning of this program, we realized that time and money might be saved by interrupting the irradiation at an exposure corresponding to the vertical dashed lines. At this point, most of the ${ }^{239} \mathrm{Pu}$ would be gone, ${ }^{240} \mathrm{Pu}$ and ${ }^{241} \mathrm{Pu}$ would be near maximum, and the quantities of americium and curium would be so low that we need not worry unduly about possible inadvertent losses. Time and money required for the chemical separation could be more than recovered by completing the irradiation at a higher neutron flux. In effect, this plan would greatly compress the time scale for the portion of each graph that lies to the right of the dashed line. High-flux operation was undemonstrated, but it could be tested during the intermission between the two parts of the curium production program.

The two-stage irradiation plan was adopted. The stages were designated Curium I and Curium II. At present, the Curium I Irradiation is complete. During the chemical processing of the irradiated plutonium, we have been testing the high-flux mode of operation. Therefore, I shall describe the status of the high-flux tests before discussing future plans for curium production.

\section{THE HIGH -FLUX TEST}

The primary objective of the high-flux test was to establish the feasibility of an accelerated irradiation for curium production, but it was designed in a way that would allow us to explore a range of operating conditions that would be applicable to a variety of possible production objectives. The achlevement of a world's record for sustained neutron flux was a secondary, though interesting, objective. The many considerations involved in the high-flux test were reviewed in detail in a series of papers $(5)$ presented at the Eleventh Annual Meeting of the American Nuclear Society in June 1965. These can be summarized as follows:

1. The entire flow of heavy water coolant was concentrated into $20 \%$ of the normal complement of fuel tubes. The considerations of interest here are the effects of high flow velocities in causing erosion of aluminum surfaces and in causing mechanical vibration.

2. The ${ }^{235} \mathrm{U}$ fuel was reduced to the minimum required for a reasonably long exposure and for a satisfactory degree of control through a $40 \%$ burnup. Here, we needed to carefully explore our ability to predict nuclear characteristics over a wide range of unusual conditions. 
3. Specific power in the fuel was increased to levels that are beyond the normal range of experience. Heat transfer limitations have been previously explored in detail in the laboratory, but the high-flux test offered an opportunity to gain operating experience at rates as high as $2.5 \times 10^{8} \mathrm{Btu} /(\mathrm{hr})\left(\mathrm{ft}^{2}\right)$.

Aside from these technical aspects, the high-flux test provided a necessary and important demonstration of operating skill and experience.

A thermal neutron flux of $5.4 \times 10^{15}$ neutrons $/\left(\mathrm{cm}^{2}\right)(\mathrm{sec})$ has been achieved. Possible further improvements would permit operation above 1016. However, at the present stage, the feasibility of high-flux irradiation for production of curium is firmly established. Such an operation can now be regarded as comfortably within reach.

Recognizing the possible benefits of the high-flux test, the Transplutonium Program Committee of the AEC's Division of Research quickly decided that as much as possible of the avallable ${ }^{242} \mathrm{Pu}$ should be Irradiated as a part of the experiment. With some extra effort by all concerned, more than half of the total available supply was assembled. The total was 525 grams of ${ }^{242} \mathrm{Pu}$; all of this was put into the high-flux core. Some of this material is in slugs prepared at Savannah River; some is in prototype HFIR targets; and some is in actual HFIR targets, which will later be transferred to Oak Ridge for further irradiation in the HFIR.

This ${ }^{242} \mathrm{Pu}$ will be irradiated throughout the high-flux test and possibly through the high-flux stage of the curium production program. The planning remains flexible and can be changed in any way that will give the best result from the combined Savannah River-Oak Ridge effort. Figure 4 shows the calculated amounts of transplutonium isotopes that will be present in these targets if the irradiation at Savannah River continues until september 1966. The various 1sotopes are shown in their conventional positions in a chart of the nuclides.

The remaining $20 \%$ of the starting material $(242 \mathrm{Pu})$ is shown to indicate the extent of burnup. The other items are products, including $244 \mathrm{Pu}$, a rare, very long-lived 1sotope of plutonium. All of the transplutonium elements, through einsteinium, are shown in at least milligram quantities. There will be at least micrograms of every possible 1sotope through $255 \mathrm{Es}$. This lays a substantial foundation for exploration upward in both atomic numbers and mass numbers.

In this continued exploration, we stand ready to help our colleagues at other locations. With encouragement and guldance from Albert Ghiorso and Ken Hulet of UCRL, we have designed and bullt a "rabbit" that w1Il 


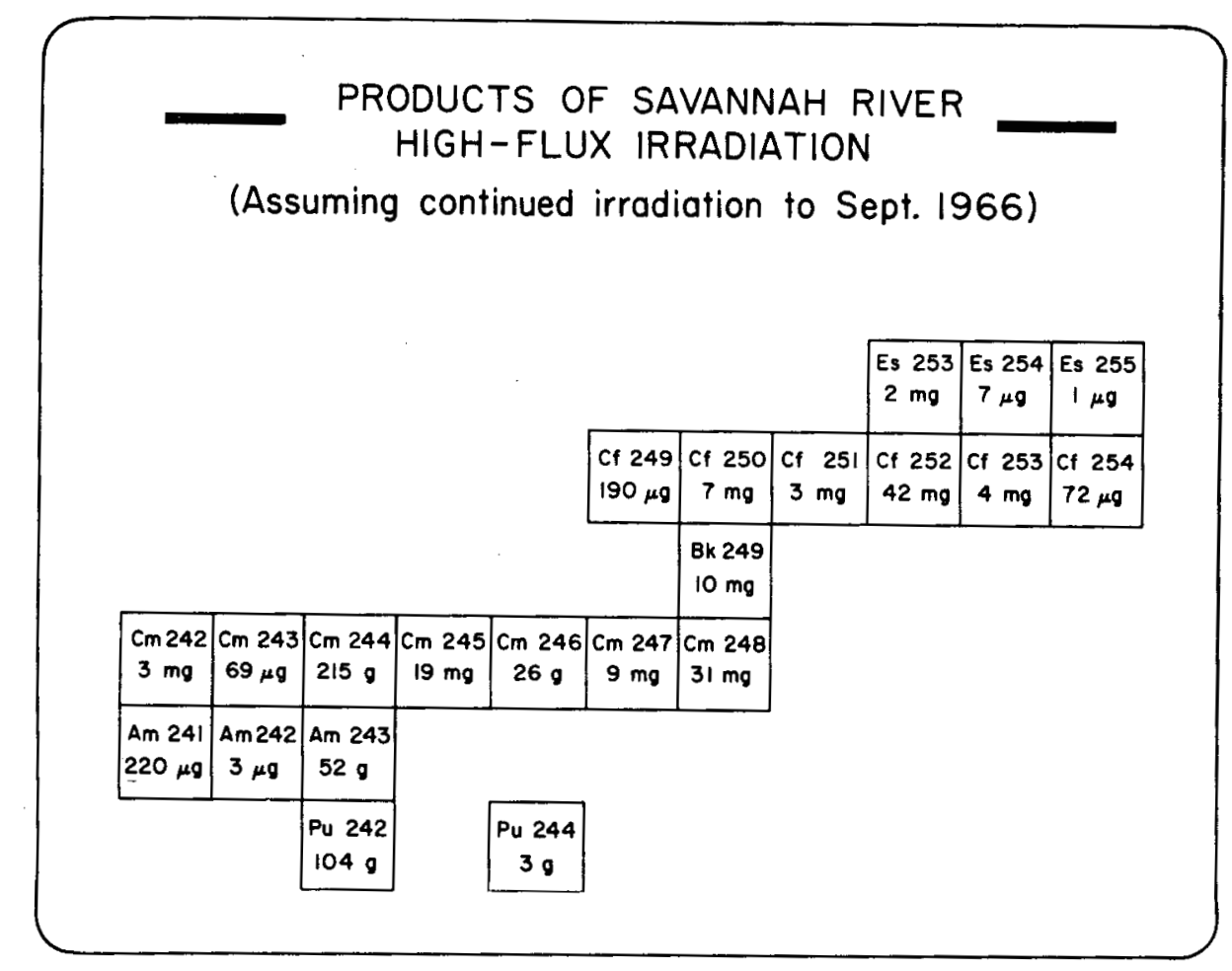

FIGURE 4

remove small samples from the reactor and dellver them to the experimenter within two to three seconds. With this rabbit, a little bit of luck, and their well-known perseverance, Ghiorso and Hulet hope to produce ${ }^{258} \mathrm{Fm}$ from $257 \mathrm{Fm}$.

Figure 5 illustrates the broad usefulness of the high-flux mode of operation. It is a full chart of the nuclides showing the many different isotopes that have been irradiated in the high-flux test. While most of these were for research programs, some of them represent production interests. High flux is useful for high speciflc activity in short-lived products. High flux is useful for stuffing neutrons into unstable atoms before they can decay into unwanted products. High flux is so useful that it will probably find continued application at Savannah River so that the type of research represented by Figures 4 and 5 can continue to be accommodated.

\section{CURIUM II}

While the high-flux test has been in progress in the reactor, the products of the Curium I irradiation have been separated and purified. The plutonium has been refabricated into new plutonium-aluminum fuel tubes. The americium and curium have been recovered and may later be 


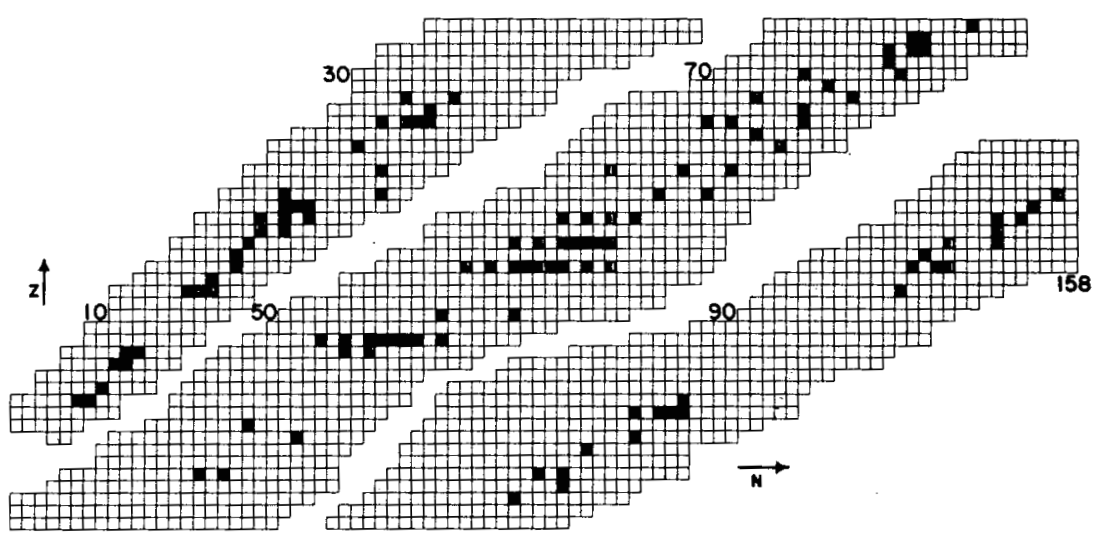

FIGURE 5

combined with the products of the second irradiation. The irradiation will be done in a mixed lattice that combines five enriched uraniumaluminum fuel assemblies with each plutonium-aluminum assembly. The neutron flux will be in excess of $10^{15}$ neutrons $/\left(\mathrm{cm}^{2}\right)(\mathrm{sec})$.

Returning to Figure 3, we should then recognize that the time scale for the Curium II irradiation will be greatly reduced so that it occuples a period of time comparable to that for curium I. However, in terms of exposure units, the shape of the set of curves on the right for plutonium isotopes will not be altered. The americium and curium curves on the left $\mathrm{W} 111$ be shifted to a lower base point, but this can be compensated by a slight increase in total exposure.

The exposure will continue until the ${ }^{242} \mathrm{Pu}$ and the ${ }^{243} \mathrm{Am}$ approach a steady-state condition. The ${ }^{244} \mathrm{Cm}$ curve will still be ascending steeply, but the exposure will be terminated when the desired production of 3 kilograms has been achieved with an adequate margin.

After the Curium II irradiation, there might be two possible plans for further programs. In the first, large-scale production of ${ }^{244} \mathrm{Cm}$ might continue with a full pipeline. ${ }^{242} \mathrm{Pu}$ and ${ }^{243} \mathrm{Am}$ would be continuously recycled, while curlum would be separated and purlfied as 
shown in Figure 6. Berkelium and californium might be recovered as byproducts. ${ }^{239} \mathrm{Pu}$ could continue to be the basic feed material. U1t1mately, plutonium that is rich in the heavier isotopes might be obtalned from the power reactor program for use as the feed.

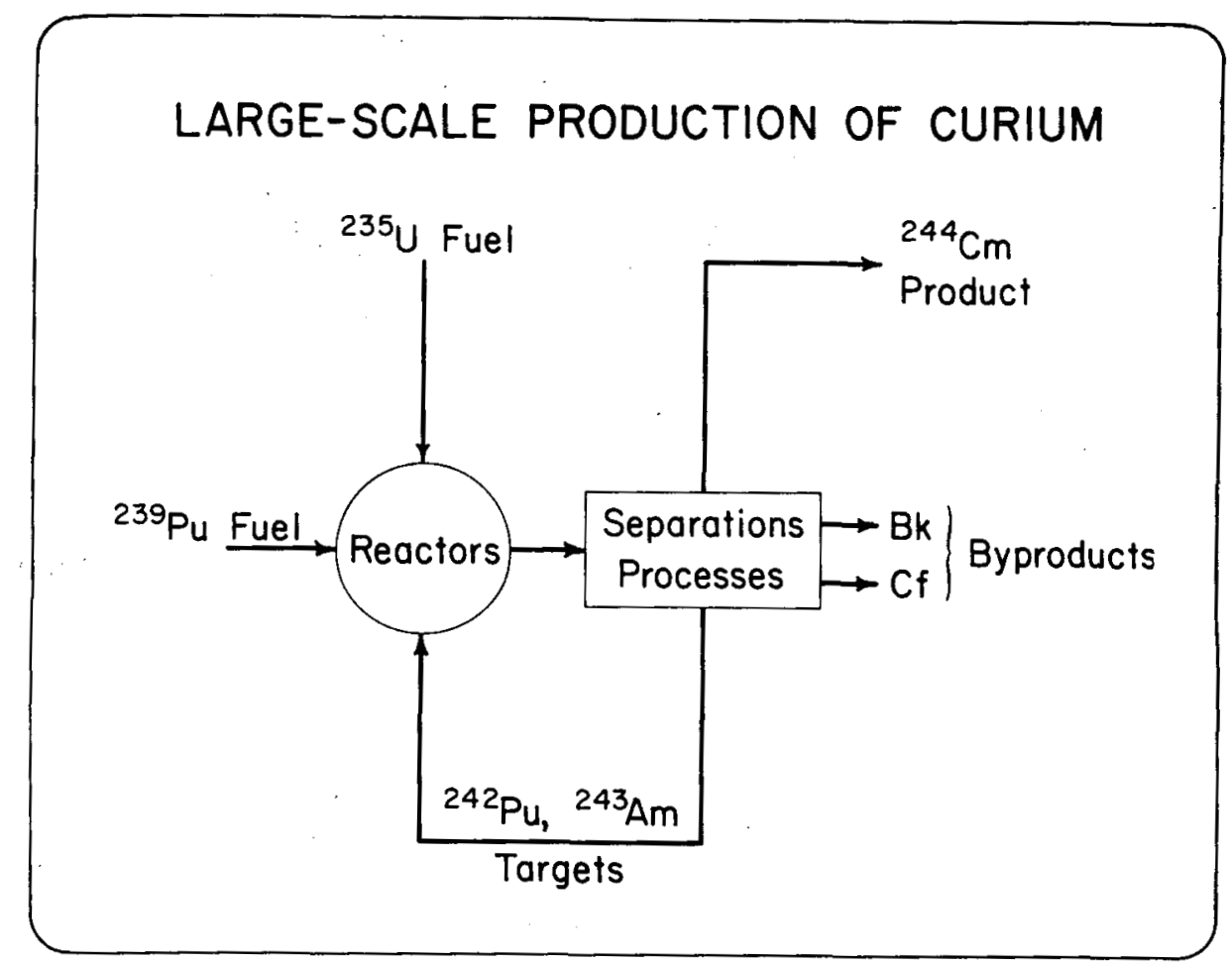

FIGURE 6

In an alternative plan, the pipeline might be drained to support a more ambitious research effort on the transplutonium elements. The amount of material avaliable for such an effort will be ten t1mes as great as that available from the transplutonium campaigns.

Regardiess of the direction chosen, the availability of transplutonium elements will be significantly increased.

The transplutonium research programs have contributed importantly to the curium production effort. The tertiary amine extraction system (Tramex process) originally developed at Oak Ridge is avallable for the recovery of americium and curium. This process has been demonstrated on a miniature scale at Savannah River and, in collaboration with Oak Ridge, has been further improved. The minlature facility has been used to process gram quantities of curium and to pave the way for a larger facility in the Savannah River Laboratory to process the 3 kilograms. 
To provide a direct comparison with Table. I, we have prepared Table II, which shows the results that might be expected from the completion of the Curium II program. Comparison with Table I indicates that the abundance of transplutonium starting materials is increased by a factor of about 10 .

\section{TABLE II}

Main Products of Curium II

\begin{tabular}{|c|c|c|c|}
\hline & $\begin{array}{l}\text { Reactor } \\
\text { Yield, g }\end{array}$ & $\begin{array}{l}\text { Separations } \\
\text { Yield, } g\end{array}$ & $\begin{array}{c}\% \\
\text { Recovery } \\
\end{array}$ \\
\hline $242 \mathrm{Pu}$ & 12500 & 12000 & 96 \\
\hline $243 \mathrm{Am}$ & 3100 & 2800 & 90 \\
\hline $244 \mathrm{Cm}$ & 3300 & 3000 & 90 \\
\hline
\end{tabular}

If the ${ }^{244} \mathrm{Cm}$ production program continues, one of the important objectives will be to recover the berkelium and calffornium. Laboratoryscale tests have shown that this is feasible. In a steady-state curium production program, one should expect to get about 5 to $10 \mathrm{~m} 11$ igrams of ${ }^{252} \mathrm{Cf}$ per kilogram of ${ }^{244} \mathrm{Cm}$ produced.

\section{CONCLUSIONS}

In summary, the results of the Savannah River activity that are most pertinent to the transplutonium program are:

1. The time scale of the over-all program has been significantly compressed.

2. In the immediate future, the abundance of starting materials $w 111$ be greatly increased, either as a result of a continuing production of ${ }^{244} \mathrm{~cm}$, or through irradiation of the byproducts of the present pilot program.

3. The high-flux mode of operation of the Savannah River reactors has been firmly established and can be useful 
for a variety of purposes. Opportunities to make more of the transplutonlum elements are likely to continue. Flux levels in excess of $10^{16}$ neutrons $/\left(\mathrm{cm}^{2}\right)(\mathrm{sec})$ are possible.

Thus, we have a situation in which both research and application appear to be moving forward, hand-in-hand. The ultimate potential is probably greater than can be visualized from either the research or the production viewpolnt alone.

\section{REFERENCES}

1. D. E. Ferguson. "ORNL Transuranium Program - The Production of Transuranium Elements." Nuc1. Sc1. Eng. 17, 435-437 (1963).

2. J. C. Eargle, C. W. Swindell, and R. I. Martens. "Large-Scale Processing of Highly Irradiated Plutonium by Solvent Extraction and Ion Exchange." Presented at American Chemical Soclety Meeting, Atlantic City, New Jersey, September 12-17, 1965.

3. W. J. Mottel and J. F. Proctor. "An Ion Exchange Unit for Recovery and Separation of ${ }^{237} \mathrm{~Np}$ and ${ }^{238} \mathrm{Pu}$." Ind. Eng. Chem. 55 (8), 27 (1963).

4. H. J. Groh, R. T. Huntoon, C. S. Schlea, J. A. Smith, and F. H. Springer. $1124 \mathrm{Cm}$ Production and Separation - Status of the Pliot Production Program at Savannah River." Nucl. Appl. I, 327-36 (1965).

5. The Savannah River High Flux Demonstration. Compiled by J. I. CrandaII. USAEC Report DP-999, E. I. du Pont de Nemours and Co., Savannah River Laboratory, Aiken, S. C. (1965). 